\title{
後天性口蓋機能不全症の一例
}

熊本大学矤学部附属病院 歯科口腔外科（主任：田縁炤講師）

$\begin{array}{llll}\text { 田 縁 } & & \text { 昭・渋 谷 征 機 } \\ \text { 児 } & \text { 玉 固 昭 } & & \end{array}$

（昭和44年 1 月30日 受理）

\section{A CASE OF ACQUIRED SOFT PALATE INSUFFICIENCY}

\author{
By
}

Akira TAEN, Seiki SHIBUYA, Kuniaki KODAMA

Dental Clinic of Medical School (Director: Lec. Akira TAEN)

Kumamoto University, Kumamoto, Japan

The authors experienced a case of acquired soft palate insufficiency in the progress of the long period, very similar to the speech of the cleft palate patients. The etiology of this case seemed the post paralysis of the palatopharyngo diphteria at his one - year - old.

We incised first the soft palate on the median line, and then formed pharyngeal flap on post - pharyngeal wall by the upper based method and sutured together both sides of the wound on the wall, and finally pharyngeal flap was transplanted to the soft palate.

As the post cure, the patient took the blowing at his home, by himself. As the consequence, the patient's hypernasality and articulatory disorder were improved, in the very short period after the pharyngeal flap operation. In five months after the operation, mono - syllable articulation was recovered from $55 \%$ to $97 \%$, three - syllable from $21 \%$, to $76 \%$ two syllable readability was recovered from $78 \%$ to $96 \%$, three - syllable from $84 \%$ to $98 \%$.

\section{緒言}

口蓋機能不全症は先天性と，後天性のものに大別され る、後者は，狭義には，口盖の北態がほとんど正常にす かかわらず, 後天的な種々の原因により，軟口蓋や，咽 頭壁の運動不全をきたし，不完全な鼻咽腔閉鎖の結果， 発音時の開放性鼻音, 飲食物の鼻腔への逆流, 咽頭腔へ の鼻汁の漏出らの障害を生じるものである.

本症の治療としては, 機能不全が急性に発現したよう な場合には，V $\mathrm{VB}_{1}$ 佣の大量投与11，ワゴスチグミンの

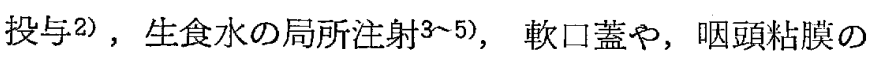
マッサージ6)，あるいは．温熱刺激療法7)等によって， 奏効をみたとする報告がみられる，てれに対して，口蓋 の機能不全が比較的長い経過をとったものに対しては， スピーチ・エイド8)の装着や，高分子材料 9 ～11) の軟口蓋

や咽頭壁への注入が行なわれている。

われわれは最近, ジフテリ一罹患後に発現した後麻痺 と考えられるきわめて長い経過をとった後天性口蓋機能 不全症の一例を経験し, 本症例に対し, 咽頭弁形成術を 行ない, きわめて短期間で劇的な効果が得られたので報 告し, 諸賢の批判を仰ぐ次第である.

症例

。患者: ○森○治 14 才令

。初診：昭和43年 7 月30日

。主訴: 発音障害, ならびに飲食物の鼻腔への漏出

○家族歴 : 同胞に口蓋機能不全, 言語障害はいない.

。生活歴 : 特記事項はない.

○既応病歴：12才の時に, 虫垂炎に罹患した以外には 特記事項はない。 
。現狱歴：胎児期，乳児期には特記すべき事項もなく 経過し, 1 才 4 力月の時に, 呼吸困難之連続した咳濑を きたしたので，某内科を受診したところ，百日咳と診断 され，2力月間の治療により症状の軽快をみた。年の後 4 才頃より, 開放性鼻音之飲食物の鼻腔への漏出に気づ き，5才に至り上記症状が乾解しないので，某大学耳鼻 科を受診したが，自然に回復するであろうと言われ，特 別の治療を受けなかった。しかし，全く回復の傾向が認 められないため, 学令に達した時, 再び同科を訪れたと ころ, 軟口蓋, 口蓋垂, 咽頭壁に生食水の注射が 2 力月 間行なわれた。しかし，全く効果が得られなかったので 放置した。その後，14才に至り，他大学耳鼻科を受診 し, 軟口盍, 咽頭壁にV B 1 の局所注射を受け, 同時に 機能訓練を受けたが, 前回と同様著効が得られなかっ た．そてで某需語クリニックを訪れたとてろ，熊本大学 歯科口腔外科に紹介されたものである.

。現症：体格, 栄養は中等度で, 四肢の運動麻痺等も 認められず，全身的には特記事項はない，顔貌 は対 称 で, 安静時, 運動時のいずれにおいてす, 顔面表情筋の 運動麻瘦は認められない. 開口は 3 横指で, 開口運動む 異常はない，軟口蓋，口蓋垂の発育は良好で，粘膜下口 蓋裂は触知し得ない，咽頭後壁には Passavant 隆起の 形成は認められるが，咽頭 反射の発現はきわめて少な く, 軟口蓋, 口蓋垂, 咽頭壁の運動は不良であるが, 噯 下障答はない。

。発音検査：発音は開放性 鼻音が著明であって，母 音, 半母音, 鼻音を除いては, ほとんど発音不能であ り，家族以外との会話はかなり困難である，また，子音 の発音に際して, 呼気のかなりの困 難さを自覚してい る. 検查は通法のごとく, 防音室で, あらかじぬ作成し てある検査表によって, 発語明暸度, ならびに発語了解 度12.13)について行なった。 その結果は第一表に示すごと く, 単音節発語明瞭度 $55 \%, 3$ 音節発語明瞭度 $21 \%, 2$ 音節発語了解度 $78 \%$ ，3 音節発語了解度 $84 \%$ ，であっ た.

。口蓋機能検査 : 呼気の鼻腔漏出量について, Baldwin式マノメーターにより, 鼻開時, 鼻閉時の経時的呼 気量を計測した。その結果は第一図に示す如く，鼻閉の 場合は, Blowing 開始上り約 0.8 秒後に2500cc に達し, その值を維持した，鼻開の場合は，約 0.5 秒で最大值約 1450ccに達した後, 急速な下降がみられ，持続時間は約 4 秒であった。 また，直径約 $25 \mathrm{~cm}$ のビニール製風船が 充満される回数について, 鼻開時及び鼻閉時について行 なわせた Blowing test の結果では, 第2四の如く，
平均，鼻閉時には 5 回，畜開時には96回を要した。 。その他の臨床検査事項

$\begin{array}{ll}\text { 脉膞 } 78 \text { 血圧 } 120 / 64 \text { 体温 } 36.7^{\circ} \mathrm{C} \\ \text { 血液検查： } \\ & \text { 赤血球数 } 524 \times 10^{4} / \mathrm{mm}^{3} \\ & \text { 白血球数 } 9500 / \mathrm{mm}^{3} \\ & \text { 血色素量 } 15.3 \mathrm{~g} / \mathrm{dl} \\ & \text { ヘマトクリット值 } 46 \% \\ \text { 朋機能： } & \text { GOT } 33 \mathrm{R}-\mathrm{F} . \text { unit } \\ & \text { GP T } 23 \mathrm{R}-\mathrm{F} . \text { unit }\end{array}$

心電図： 異常所見なし

。臨床診断 : 後天性口蓋機能不全症

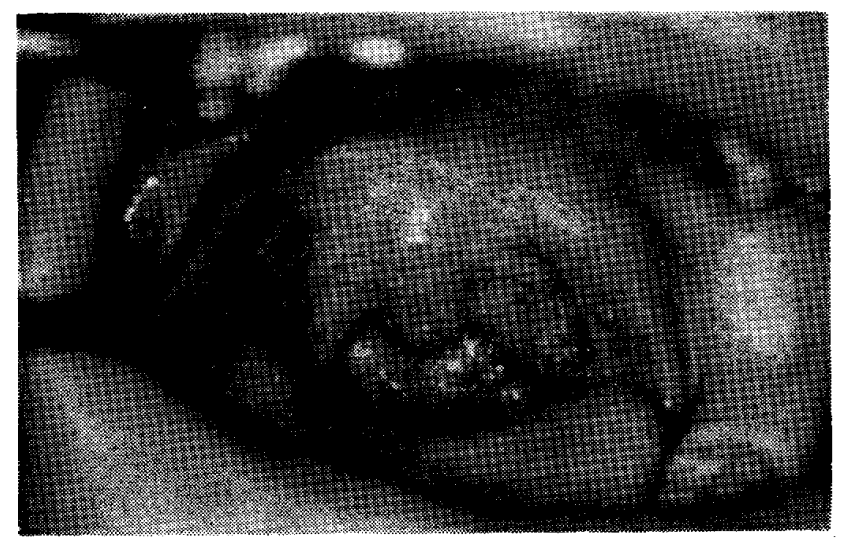

写真 1 術前口腔内所見

処置および 経，過

昭和49年 7 月 30 日入院せしめた. 本症例は口蓋機能不 全が長期にわたっているため. 薬物療法, 刺激療法など による神経の賦活によって，鼻咽腔閉鎖を期待すること は效果が得難いと考えられたので，一次的に鼻咽空の狭 少化を目的とし，Padgett一永井氏法に従って，弁の基 底部を上方にとる上茎法を用いた咽頭弁形成術を行なっ た.

患者は通法のごとく，経口気管内插管による全麻のも とに，まず口蓋垂ならびに，これに隣接する軟口蓋に矢 状正中切開を加え, 切開された軟口蓋, 口蓋垂を左右に 分け，珚頭後壁を可及的直視下におく，そてで咽頭弁は Passavant 隆起の直下が基部となるような部で，かつ， その基部が上方となるように，下方に長さ $2 \mathrm{~cm}$ 巾 1 $\mathrm{cm}$, 厚さ約 $7 \mathrm{~mm} の U$ 字型をした粘 膜筋肉弁を形成す る、咽頭弁を採取した後咽頭壁の創控は咽頭壁を左右よ り減張させて, 縫合閉鎖する, その結果, 咽頭側壁は正 中に引きよせられ，咽頭腔の狭少化の助けとなる，得ら れた咽頭弁はすでに切開している軟口蓋の創面と, 充分 なる直視下のむとに，まず，鼻腔側粘膜面を縫 合形成 し，次に軟口蓋筋肉部と弁の筋肉部を縫 合して，創面 を閉鎖し，手術を終了した. 術中の出血 量は重量法で 
15gであった。

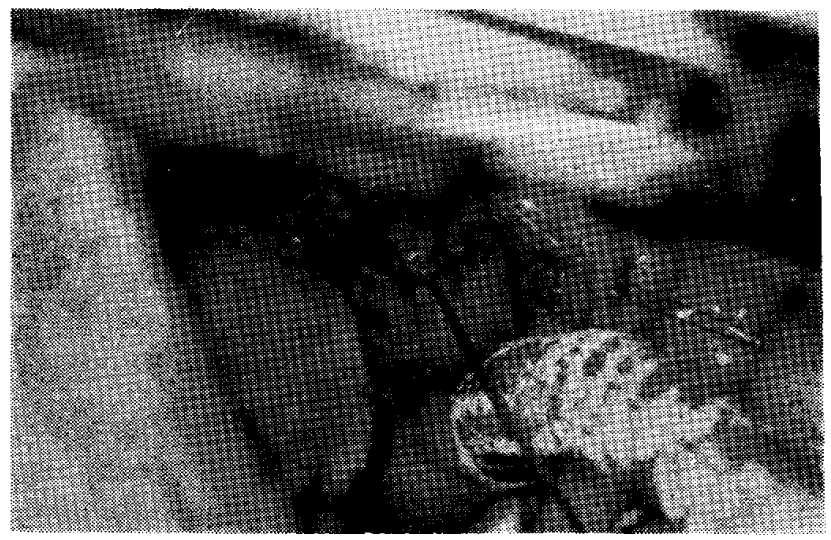

写真 2 術中口腔内所見 咽頭弁形成術

術後, 咽頭, 軟口蓋部に轻度の自発痛, 跙下痛があ り, 食事の掑取困難を自覚した以外には, 出血, 呼吸困 難等，不快事項の発琴は認められなかった。術後 4 日目 頃より上記症状はほとんど消失し，開放性鼻音は他覚的 そも，軽減が明らかに認められ，また，音調の高音化む 認められたので, 術後11日目に退院せしめた。退院後, 自宅において Blowing, Supping, Chewing, Gurgeling，などの自己機能訓練のみを行なわせた。

第 1 図 肺活量計による鼻腔漏出量

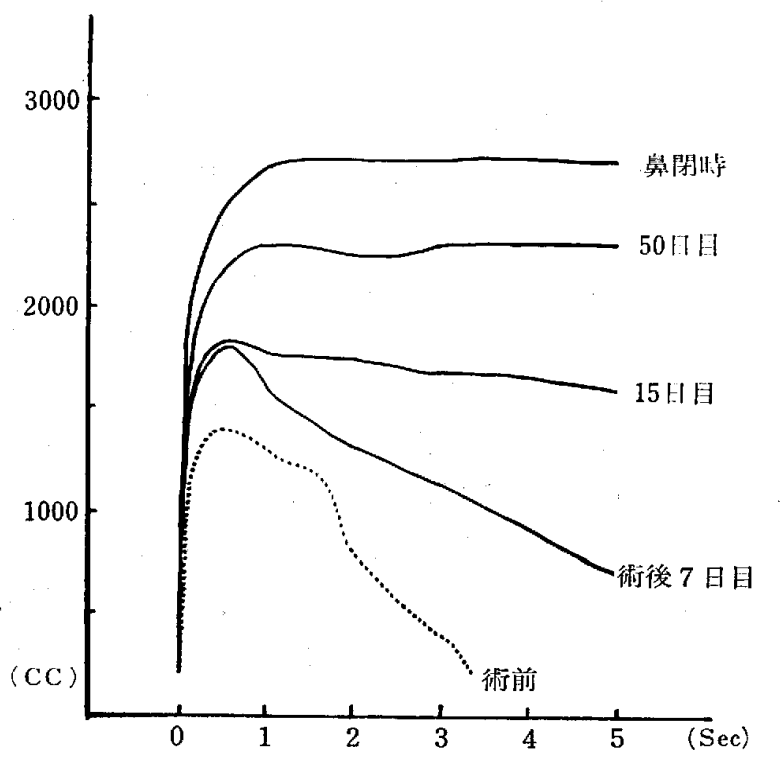

Baldwin 式マノメーターによる呼気の鼻腔漏 出は, 第 1 図のどとく, 術後 7 日目では計測開始より約 0.5 秒 後に最大值 $1750 \mathrm{cc}$ 亿達し, 術前と比較して呼気量の経時 的減少の改善が認めら机いる.15日目ではさらにその 改善が著明となり，30日目には0.8 秒後に最大值 $2400 \mathrm{cc}$ に達し, 経時的にその值をほぼ維持している。 また，風 船吸きの検査では，第二図の如く鼻開時の回数が術前に
第 2 図 ビニール風船による Blowing test.

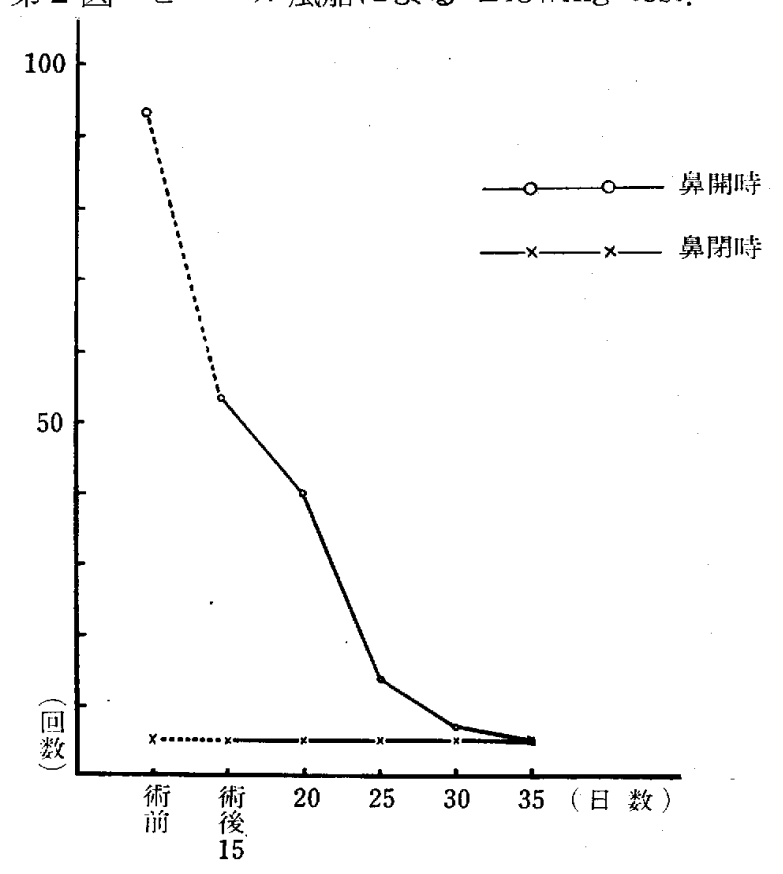

第 1 表 発 音 検 査

\begin{tabular}{|c|c|c|c|c|c|}
\hline & \multicolumn{2}{|c|}{ 発語 明 瞭 度 } & \multicolumn{2}{|c|}{ 発語了解度 } \\
\hline & & 単音節 & 3音節 & 2 音節 & 3 音節 \\
\hline 術 & 前 & 55 & 21 & 78 & 84 \\
\hline 術 & 1 月 & 85 & 75 & 90 & 96 \\
\hline 後 & 5 月 & 94 & 76 & 96 & 98 \\
\hline
\end{tabular}

第3図

発語明瞭度、発語了解度の回復成績

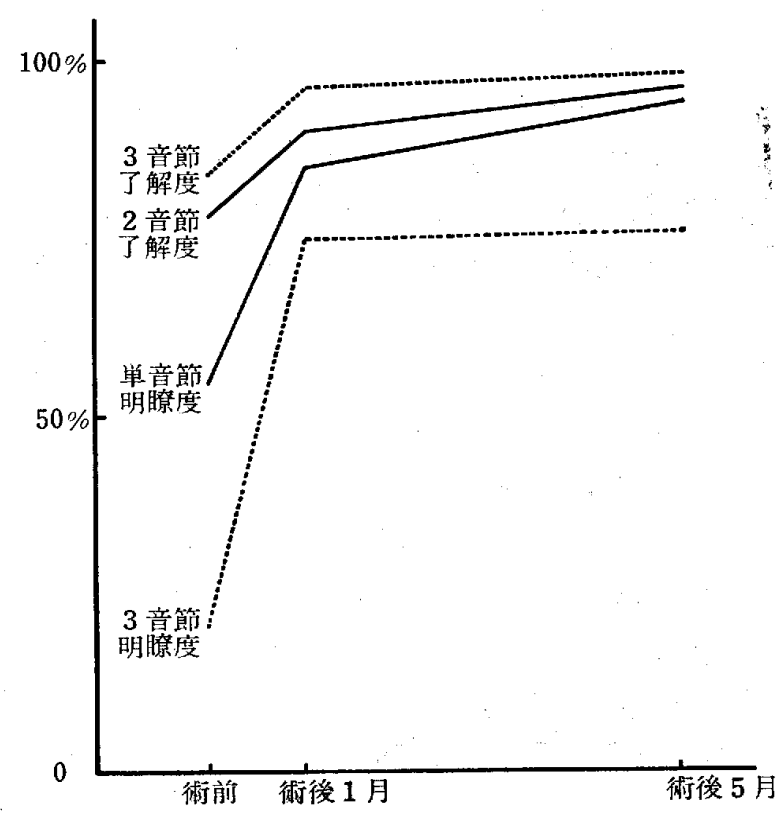


比較して急激に減少し，96回から45回となっており，術 後35日目には，舅閉時の回数 5 回之一致した.さらに発 音は術後より音調の高音化が明らかに認められ, 患者 も, 発音時, ことに子音の発音において呼気の困難性の 低減を自覚した。術後の発語明瞭度, 発語了解度検査の 結果は第 1 表に示すごとくであり，術後 5 月目では，そ れぞれ94\%，76\%，96\%，98\%，であり，著明な改善が 認められており，第3者との日常会話屯ほとんど完全に 行なわれるようになった。

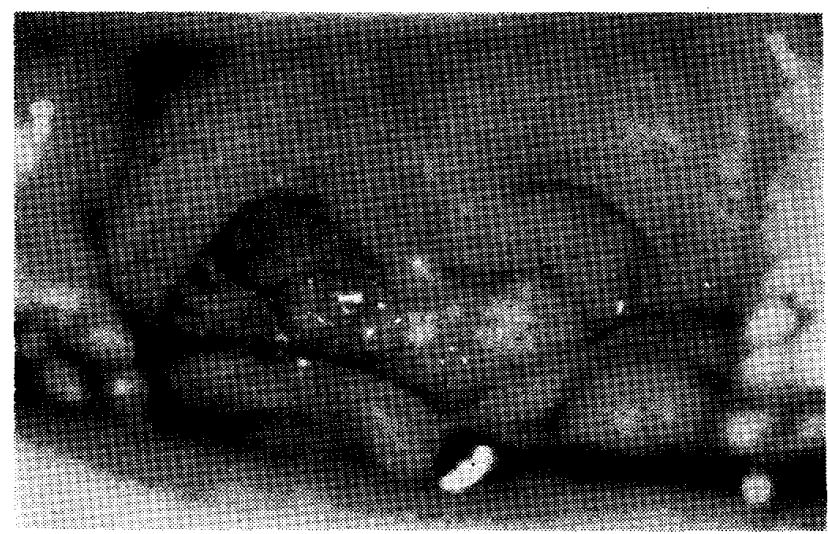

写真 3 術後口腔内所見 (5月)

\section{総 括 並びに考按}

口盖機能不全症には，広義には，口蓋裂や，腫㾘，外 傷などによる共鳴腔の明らかな形態異常によるもののほ か，その形態に著明な変化が認められないにもかかわら ず, 先天性や後天性に開放性鼻音の発現, 飲食物の鼻腔 内逆流などの障害を表わす場合があり，1892年，L'insuffisance vele ・ valatine として Lermoyez14)により報 告されて以来，二，三の報告15,16)が見られる，Blockosma17)はこのような場合を，口蓋機能不全症として， 口 蓋が先天的に短少な場合，口蓋の筋肉が不活性な場合， 咽頭の筋肉の運動が不良な場合，咽頭门蓋が過度に深い 場合などを挙げている。つまり，わずかな些鳴腔の形態 異常をむ含めて，咽頭，軟口盍の運動不全により，鼻咽 腔閉鎖が完全に行なわれない結果，開放性鼻音や，飲食 物の逆流などを生じる場合を口盍機能不全症としてい る，その原因としては，諸家2,18,19)により，つぎのよう な場合が言及されて和り，すなわち

1. 先天性口葐機能不全症

2. 後天性口蓋機能不全性

a) 中枢性

ヒステリー，小児麻瘏，脊髄瘦，フリードライヒ 氏病, 多発性硬化症, 筋萎縮性側索硬化症

b) 末梢性
ヂフテリー性後麻瘏，インフルエンザ，流行性耳 下腺炎，猩紅熱，腸チフス，口蓋扁桃の肥大，腺 様増殖, 扁摘, 外傷, 疲痕, 腫瘍の圧迫, 浸潤,

などが挙げられている。

本症例の場合，口蓋機能不全を生じた原团について考 擦すると，患者は1才 4 力月の時に，百日咳に痽患した とする既応があり，呼吸困難，激しい咳嗽，発熱，など ヂフテリーとも考えられる症状すあり，同疾患の䍜患以 前には，開放性鼻音，飲食物の鼻腔への逆流などがみら れなかったとする点から，ヂフテリー後麻痺の疑がきわ めて強い，従って，本症例はデフテリーの後麻瘏による 後天性陳旧性口蓋機能不全とも考えられる。

音声言語の構成機序としては呼気により，声帯で作ら れた音を, 山唇, 舌, 軟口蓋, 咽頭後壁らの共鳴腔を, 大脳皮質の言語中枢に従った運動により，種々な形態に 変化させて共鳴した結果生じるのである。従って，一定 の言語音は一定の音と口腔，その他の共鳴腔の形態によ り決定される。そこで，発音時における鼻咽腔閉鎖は構 音譏能上，重要な役害りの一つを行なうわけである。そ の機序としては, 要約すると, 軟口蓋の挙上, Passavant 隆起の形成による咽頭後壁の前方への突出，唄頭側壁 の正中方向への収縮によって行なわれる。そこで，本症 のごとき口蓋機能不全のため, 妍静時には形態的に正常 であると認められても，上述の部位のいずれかの部に運 動不全が生じれば，発音時の鼻咽腔に閉鎖不全を生じ， そのため呼気の鼻腔漏出がある。その結果，口腔内压が 低減し，磨擦音，破裂音らが発音不能となる。乙れらの 音は鼻腔漏出が多少認められて屯，四腔内王が充分あれ ば発音が可能と言われ，松矢20)は磨摖音，破裂音の発 音のためには，鼻咽腔漏出の有無にかかわらず， $50 \mathrm{~mm}$ $\mathrm{H}_{2} \mathrm{O}$ 前後の口腔内压が必要であると述べている。

本報告例の治療は，きわめて長い経過をとったヂフテ リ一性の口蓋機能不全症が疑われており，すでに生食 水, $\mathrm{VB}_{1}$ の軟口蓋や咽頭壁への局所注射，機能訓練が行 なわれているが，いずれあ奏效していない，従って，本 症の如く機能不全がきわめて長期間にわたっているよう な場合には，薬物療法，刺激療法らによる笳の運動回復 による鼻咽腔閉鎖は期待できないと考えられる.そこで, このような陳旧性の口蓋機能不全症に対する治療法とし ては，何らかの方法で鼻咽腔の狭少化をはかり，呼気の 鼻腔漏出を防止する事が必要とされる，従来まで行なわ れている方法としては，非観血的には古くは咽頭壁，軟 口盖に対するパラフィンの注入9)が挙げられ，また，ス ピーチ・エイドの装着8) が推賞されているが，詳細では 
ない，その外シリコーン樹脂10)や,テフロン11)の咽頭壁, 軟口蓋に対する注入についても報告がある．観血的療法 に関しては，比較的記載が少なく，Randall21)，Owsley 16), Porterfield22), Williams23)，等に上って咽頭弁形 成術を行なった報告があり，いずれあ好結果を得，特 に Randall は劇的な効果があったとしている．本邦にお いては，われわれの報告例24) 以外には記載が見られな い.

咽頭弁形成術は元来，口蓋裂患者の口蓋機能を改善す るための術式であって，口蓋形成後僟能不全が遺残し た場合や、形成手術が遅れた場合などに行なわれている。 本法は Trendelenburg 氏による動物実験に端を発し， Passavant 氏により，臨床に初めて試用されている。琴 在，并の基底部を下方にとる Schönborn 氏法，基底部 を上方にとる Padgett 氏法とが使用されている，本症例 に対して，われわれは後者の方法をとった．すなわち， Padgett－永井氏25）法による基底部を上方に求めた方 が，咽頭弁形成術後の般痕収縮により，好適と考えたた めである。本報告例においてす,術後 4 日目で,音調の変 化が自覚的に屯，他覚的にも明らかに認められ，形成手 術による一次的な鼻咽腔の狭少化の效果が明らが認め られている，すなわち，同年令の口蓋裂患者等の形成手 術に比較して, きわめて短期間のうちに, 開放性鼻音の 消失, 構音障害の改善が得られている。従って, 形態の 暴常が認められないにもかかわらず，機能不全が長期間 にわたったような口蓋や，咽頭の麻痺，あるいは運動不 全の場合には，スピーチ・エイドの装着では，これを長 期間あるいは永久的に常用する事で，不潔となる可能性 や，破折，誤揹の恐れ屯あり，また，パラフィン，シリ コーン樹脂, テフロン等, 可塑性高分子材料の咽頭壁の 注入では，生体内で異物として存在するための障害を起 す可能性がある．乙れに対して，われわれの行なった観 血的処置によれば，解剖学的形態に対してさらに改善を 加え，鼻咽腔の狭少化を行なったあのであるから，永久 的で，かつ咽頭弁，ならびに周囲軟組織が術後の機能訓 練により，その運動の賦活を行ない，すみやかな機能回 復が得られるあのであると考える。

\section{結論}

1. 著明な開放性鼻音と構音障害を伴なった，口蓋裂 患者の音声にきわめて類似したデフテリーの後遺症と思 われる長い経過をとった後天性口蓋機 能不全症の 1 例 を経験した。

2. 本症例に対し，上茎法による咽頭弁形成術を行な った結果, 比較的短期間のうちに, 開放性鼻音, 構音障
害など，異常音声の著明な改善が得られた。

(本論文の要旨は, 九州歯科学会, 昭和44年 1 月例会に おいて発表した）

\section{文献}

1. 手塚 正；ヂフテリー後麻㾌（軟口蓋）に対する頸 動脈注射に上る1治験例：耳鼻咽喉科，22，71 72, (1950).

2. 中村文雄他; 軟口蓋麻瘦 : 耳鼻咽喉科, 24, 66 69, (1952).

3. 方円正久; 延䯣灭白質炎之㫶下㜔害: 开鼻咽喉科, 26, 479 481, (1954).

4. 青村瑤子他; 婎婦にみられた口蓋帆麻瘏症例：耳鼻 咽喉科, 21，356 357, (1949).

5. 菅野享他; 軟口蓋麻煛の 2 症例 : 耳鼻咽喉科, 31 , 483 489, (1959).

6. 丸岡修三他；ヂフテリア後麻瘦の 1 重篤例 : 耳鼻咽 㗋科, 34, 1055 1058, (1962).

7. 河野雅久他; 機能性開鼻声の 1 治験例：正鼻咽 㑨 科, 24, 340 342, (1952).

8. 中田幸代; 口蓋裂の言語治療：开鼻咽喉科，38， 1417 1425, (1906).

9. Eckstein, H. ; Hartparaffininjektionen in der hintere Rachenwand bei angebornen und erworbenen Gaumendefekten : Berl. Klin. Wochenschr, 31, 1185 1187, (1922).

10. Blockosma, R. ; Correction of velopharyngeal insafficiency by Silastic pharyngeal implant: Plastic, reconstruct. Surg., 31, 268 274, (1963).

11. Ward, P. H. et al. ; Teflon injection to improvevelopharyngeal insufficiency: J. Speech and Hearing Disorders, 31, 267 273, (1966).

12. 明瞭度委貣会；明瞭度試験法の規準：日本音響学 会, (1961).

13. 田縁昭他; 口蓋裂患者の言語明瞭度と了解度との関

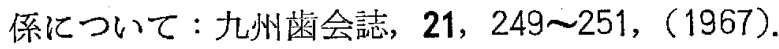

14. Lermoyez, M. ; L'insuffisance vele-valatine : Ann. d' otolaryng, 18, 161 205, (1892).

15. Owsley, J. Q. et al. ; Cleft palate speeeh in absence of cleft palate: General Practitioner, 33, 93 98(1966).

16. Owsley, J. Q. ; Cephalometric Evaluation of palatal Dy sfunction in patients without cleft palate :Plast. and Reconstruct. Surg, 39 (6), 562 
568, (1967).

17. Blocksma, R. ; Silicone implants for velopha ryngeal incompetence, A Prognosis report: $\mathrm{Cl}$. eft palate J., 1, 72 81, (1964).

18. 坂田正；非ヂフテリア性軟口蓋麻痺について：耳鼻 咽喉科, 24, 180 182, (1952).

19. 加納隆; 扁摘後にみられた一過性音声㤩語障碍の 2 例について；耳舅咽喉科，25，814 816，(1953).

20. 松矢篤三；口盖裂患者の異常音声の発生機序に関す る基礎的研究; 阪大幽学誌，13，45 57，(1968).

21. Randall, P., et al. ; Cleft palate-type speech in the absense of cleft palate plast. and Reconstruct. Surg., 25, 484 495, (1960).
22. Porterfield, H. W. et al. ; Hypernasality in noncleft palate patients : Plast. \& Reconstruct. Surg. 37, 216 220, (1966).

23. Williams, H. B. et al. ; Completion of speech improvement in cases of cleft Palate after two methods of pharyngoplasty : Plast. \& Reconstruct. Surg., 30, 36 42, (1962).

24. 田縁昭他；口蓋咽頭弁移植法を行なった口蓋運動麻 瘦患者について : 九州歯会誌, $21,286 \sim 287$, (1967).

25. 永井 孷; 口蓋裂手術：第16回日本医学会総会学術 講演集，589～602，(1963). 